\title{
A coleção Matemática - Curso Ginasial, do SMSG: uma análise
}

Analysing the books from the Mathematics for Junior High School Collection (Matemática - Curso Ginasial)

Tatiane Taís Pereira da Silva ${ }^{1}$ Antonio Vicente Marafioti Garnica²

\section{Resumo}

Fundamentado nas diretrizes da Hermenêutica de Profundidade de John Thompson, este artigo analisa a coleção Matemática - curso Ginasial, do SMSG, cuja versão brasileira é de 1967. A análise ressalta certo distanciamento entre a natureza dessa Coleção e as características que mais comumente têm sido atribuídas ao Movimento Matemática Moderna.

Palavras chave: Coleção Matemática-Curso Ginasial, SMSG, Matemática Moderna, hermenêutica de profundidade.

\section{Abstract}

This paper presents an analysis of the Brazilian version of the books entitled Mathematics for Junior High School (Matemática - Curso Ginasial, in Portuguese), produced by SMSG and translated and edited in Brazil in 1967. The framework to develop such analysis was given by John Thompson's Hermeneutics of the Depth and its results points to a sharp distinction between the approach to the math content in such books and the characteristics usually brought to the scene when defining what the New Math Movement was.

Keywords: Mathematics for Junior High School (Matemática - Curso Ginasial), SMSG, New Math Movement, Hermeneutics of the Depth

\footnotetext{
${ }^{1}$ UNESP - Rio Claro | tati_matematica@hotmail.com.br

2 Departamento de Matemática da UNESP de Bauru | vgarnica@fc.unesp.br
} 


\section{Matemática Escolar, História da Matemática Escolar, História da Educação Matemática: breve introdução}

Caracterizar cultura escolar e cultura matemática escolar é, por certo, desnecessário se tomarmos como referências os inúmeros textos que têm sido produzidos apoiados nessa caracterização. Para as nossas intenções, neste artigo, basta afirmar que os estudos sobre a cultura escolar tratam das formas simbólicas que circulam pela escola. Formas simbólicas -e essa expressão será retomada na continuidade deste texto - são, grosso modo, construções humanas intencionais e que, como tal, servem para estabelecer, manter ou subverter relações de poder, no caso, relativas à escola. Que a matemática e a matemática escolar são formas simbólicas é também uma afirmação que se sustenta claramente - mesmo à luz dessa caracterização apoucada do que é uma forma simbólica. É também bastante razoável supor que são várias as formas simbólicas que circulam pela escola e compõem, assim, a cultura escolar, e que também a escola é uma forma simbólica. Compreender a cultura escolar "numa perspectiva histórica" é, em si, expressão hiperbólica, redundante, dado que podemos tentar auscultar a cultura escolar de um passado recente, de um passado distante ou mesmo do presente, mas de forma alguma podemos compreender a cultura escolar (ou qualquer coisa que seja) apartados da história. Se insistimos aqui nessa redundância, afirmando que um dos objetivos deste artigo é contribuir para compreender a matemática escolar na cultura escolar numa perspectiva histórica, é porque queremos realçar que nossas apreensões terão como apoio fundamental teóricos da historiografia ou que dialogam com a historiografia.

Compreender a matemática na cultura escolar implica considerar inúmeras formas simbólicas, dissemos, e certamente essa compreensão se faz aos poucos, já que não se pode abordar, ao mesmo tempo, todo um campo complexo em que circulam formas simbólicas das mais distintas. Este artigo tem, assim, uma pretensão muito específica: estudar, a partir de um referencial teórico metodológico específico - a Hermenêutica de Profundidade - uma das formas simbólicas que circula no ambiente escolar - o livro didático. Mais especificamente ainda, pretendemos examinar hermeneuticamente uma série de livros didáticos, a edição brasileira da coleção Matemática - curso ginasial, composta pelo SMSG (Schoo/ Mathematics Study Group) e traduzida por Lafayette de Moraes e Lydia Condé Lamparelli em meados da década de 1960. Se esta é a intenção deste artigo, sua pretensão é contribuir - ainda que timidamente - para a compreensão da Matemática na cultura escolar numa perspectiva histórica e, mais propriamente, para os estudos sobre História da Educação Matemática no Brasil.

\section{Hermenêutica de Profundidade: texto, contexto e paratexto}

As disposições sobre Hermenêutica de Profundidade em que nos apoiamos estão dadas principalmente por John Thompson, sociólogo inglês, assumidamente influenciado por Paul Ricoeur, em sua obra Ideologia e Cultura Moderna: Teoria social crítica na era dos meios de comunicação de massa (THOMPSON, 1995) e por alguns (ainda poucos) pesquisadores brasileiros (ROLKOUSKI, 2006; OLIVEIRA, 2008; CARDOSO, 2009; ANDRADE, 2012; PARDIM, 2013 e SILVA, 2013) que têm mobilizado esse referencial em suas pesquisas. 
A Hermenêutica de Profundidade (HP) é um referencial teórico metodológico plasmado sobre o conceito de formas simbólicas. Em síntese, a HP é um modo de analisar/interpretar/compreender formas simbólicas que envolvem, num processo de retroalimentações, uma hermenêutica do texto ${ }^{3}$ e do contexto ${ }^{4}$.

Segundo Oliveira (2008, p. 37), "[...] as formas simbólicas são construções carregadas de registros de significados produzidos em condições espaço-psíquico-temporais específicas - e impossíveis de serem identicamente reproduzidas - de um autor" e podem ser caracterizadas a partir de cinco aspectos: (a) formas simbólicas são constituídas com uma intenção (aspecto intencional). Os livros didáticos, por exemplo, são produzidos por um autor com uma determinada finalidade, que pode ser a de auxiliar no processo de ensino e aprendizagem, apresentando aos professores como, por que e em qual momento abordar um conteúdo em sala de aula; (b) uma forma simbólica é produzida de acordo com alguns pressupostos que possibilitam que outras pessoas as compreendam, permitindo, assim, uma comunicação entre a forma simbólica e o hermeneuta (aspecto convencional). Nos livros didáticos de matemática, por exemplo, a própria linguagem matemática possui sua convenção bem estruturada que requer certa habilidade para ser interpretada; (c) os elementos internos de uma forma simbólica são estruturados de uma forma conexa, para que se possa compreender e relacionar os elementos que a compõem (aspecto estrutural). Um livro didático, por exemplo, é estruturado quanto ao modo de apresentar os conteúdos, os momentos em que são propostos exercícios, problemas, usadas metáforas e ilustrações, mobilizados métodos didáticos e pedagógicos etc (OLIVEIRA, 2008, p. 36), (d) uma forma simbólica sempre se refere a algo (aspecto referencial). O livro didático se refere ao conteúdo matemático e às possibilidades metodológicas para o seu ensino, seu objeto referencial é a Educação Matemática (OLIVEIRA, 2008, p.36); (e) o contexto social no qual que a forma simbólica está inserida influencia na sua produção (aspecto contextual). Isso implica que para fazer uma leitura plausível de uma forma simbólica precisamos considerar o contexto em que a mesma foi produzida e/ou apropriada. No caso dos livros didáticos, além dos aspectos social, político e cultural, devem ser consideradas, por exemplo, as teorias e políticas educacionais da época em que a obra foi elaborada e/ou publicada.

A trajetória de interpretação de uma forma simbólica pela HP é feita em três momentos analíticos (uma análise formal - ou discursiva -, uma análise sócio-histórica e um momento de interpretação/reinterpretação da forma) que, certamente, não são estanques nem autosuficientes: é na retroalimentação entre esses momentos que a hermenêutica da forma se dá.

\footnotetext{
${ }^{3}$ Texto, segundo Paul Ricoeur (1969), é tudo aquilo fixado pela escrita, mas essa é já uma apreensão um tanto quanto limitada, posto que diz apenas de textos escritos. Numa apreensão mais geral, texto é a compreensão resultante de uma leitura. Para nossas intenções, entretanto, essa apreensão primeira, de uma das obras de Ricoeur, é suficiente, ainda que, no conjunto de sua filosofia - cuja intenção é desenvolver uma hermenêutica da existência - a noção de texto seja bastante estendida para abarcar outras formas além da escrita.

${ }^{4}$ Contexto, para simplificação, será tomado aqui como tudo aquilo que cerca o texto, dentre o que estão as dinâmicas de sua elaboração e apropriação, os espaços e os agentes envolvidos em sua produção e circulação etc.
} 
Na análise formal, o hermeneuta volta seu olhar para os conteúdos internos da obra, descreve detalhada e criteriosamente a obra analisada. Bastar-se à análise formal, entretanto, não configura o todo da hermenêutica: a investigação sobre os elementos "internos" à obra - no caso do exercício que pretendemos desenvolver neste artigo, um livro didático - é apenas parte da hermenêutica, ainda que seja instância inequivocamente necessária e muitas vezes inicial, dependendo da habilidade do hermeneuta em trabalhar com formas simbólicas similares. Segundo Thompson (1995), "embora vários tipos de análise formal, estatística e objetiva sejam perfeitamente apropriadas e até mesmo vitais [...] esses tipos de análise constituem, na melhor das hipóteses, um enfoque parcial ao estudo" (p.358). Para efetivar a HP o hermenêuta apóia-se, quando julga necessário, em indicadores, teorias e procedimentos complementares além das formas propostas por Thompson ${ }^{5}$. Para a análise formal de uma hermenêutica à obra Matemática - curso ginasial nos apoiamos na noção de paratextos, como apresentada por Gérard Genette (GENETTE, 2009). Este autor define paratexto como "[...] aquilo por meio de que um texto se torna livro e se propõe como tal a seus leitores, e de maneira mais geral ao público" (p.09). Dentre outros, podem ser considerados como paratextos o nome do autor, os títulos, os subtítulos, prefácio, dedicatórias, ilustrações, anexos, o material do livro, da capa, as artes gráficas nele presentes, as indicações iniciais (como nome da editora, endereços, tamanho de margens, a tipologia das letras e espaços em branco, por exemplo), os materiais usados para a divulgação do livro etc. Genette nos dá não apenas uma listagem dos paratextos que devem/podem estar na mira do hermenêuta, mas discorre sobre cada um deles, contextualizando-os historicamente e provendo seu leitor de inúmeros exemplos e "chaves analíticas". A operacionalização dessa concepção de paratexto junto à HP, porém, deve ser vista com cautela pois não é tão direto o diálogo entre os dois referenciais. Genette quando fala "texto", fala "texto escrito", isto é, uma forma simbólica multifacetada, mas específica, ao passo que Thompson quando fala "texto", fala "forma simbólica" e, portanto, de algo mais geral que um discurso fixado pela escrita. Entretanto, conciliar os referenciais de Genette e Thompson, interconectar análise de paratextos e HP, aqui, não trará problema algum, posto que a forma simbólica que pretendemos analisar é um texto escrito.

Formas simbólicas, reiteramos, estão inseridas em contextos sociais que influenciam sua produção e o modo como são mobilizadas. Dessa forma, para uma maior plausibilidade à interpretação desses materiais, Thompson propõe que na análise sócio-histórica o foco da

5 Segundo Thompson (1995), a análise formal pode compreender uma análise narrativa, argumentativa e sintática. Uma análise sintática foca-se em características gramaticais do discurso, buscando "marcadores de modalidade, através dos quais os locutores indicam os graus de certeza ou realidade ligados com a preposição (por exemplo, 'pode ser', 'talvez', 'possivelmente'), o sistema de pronomes empregado [...], marcadores associados às diferenças de gênero" (THOMPSON, 1995, p. 373). No que se refere à análise narrativa, considerando narrativa como expressão de um discurso que "conta uma história", analisa-se o conjunto de elementos que constituem essa história. A análise argumentativa pretende "reconstruir e tornar explícitos os padrões de inferência que caracterizam o discurso" (THOMPSON, 1995, p. 374). Trata-se, segundo Andrade (2012), de tentar compreender o que o texto diz e como diz, como as linhas, palavras, referências, articulações, citações etc, constroem a trama de modo a explicitar coerentemente algumas intenções tomadas, então, como as intenções do autor (do ponto de vista de um leitor específico - aquele que se propõe a analisar hermeneuticamente o texto). 
investigação seja o contexto em que as formas simbólicas foram elaboradas e/ou apropriadas.

Segundo Cardoso (2009, p. 30) a análise sócio-histórica tem como objetivo identificar e descrever as situações espaço-temporais em que as formas simbólicas são produzidas e recebidas; analisar o campo de interação das formas simbólicas: trajetórias que determinam como as pessoas têm acesso às oportunidades de usá-las - emprego dos recursos disponíveis, esquemas tácitos de conduta, convenções, conhecimento próprio inculcado nas atividades cotidianas; analisar as instituições sociais, isto é, as regras e os recursos em uso nas relações sociais; examinar as práticas e as atitudes das pessoas que agem a favor da instituição social; considerar o papel das estruturas sociais para a criação e divulgação da forma simbólica; e, por fim, conhecer os meios técnicos de constituição de mensagens e como eles são inseridos na sociedade. Assim, a análise sócio-histórica extrapola a obra "em si", pois exige do hermeneuta um mergulho nos aspectos sócio-político-econômicoculturais da época, cujos resíduos podem ser acessados/interpretados.

A Interpretação/Reinterpretação, o "terceiro" momento analítico da HP, desenvolve-se com o estudo das aproximações e divergências detectadas num cotejamento entre os elementos que os momentos "anteriores" de análise permitiram construir. Para Oliveira (2008), esse momento de análise evoca "[...] a reflexão sobre os dados obtidos anteriormente, relacionando contextos e elementos de modo a construir um significado à forma simbólica" (p.43). No caso dos livros didáticos, é quando são evidenciadas, segundo a perspectiva do hermenêuta, as intenções manifestadas pelo autor e o modo como essas intenções podem ter sido apreendidas pelos seus leitores e como se transformaram em práticas escolares.

A análise da forma simbólica, no processo metodológico da HP, constitui-se quando olhamos para os seus aspectos internos e contextuais e conseguimos tecer relações entre esses momentos, valendo-nos de um para compreender o outro. Esse movimento de análise desenvolve-se durante a Interpretação/Reinterpretação, que, por sua vez, não ocorre de forma independente dos outros movimentos, nem é meramente posterior a eles, mas percorre todo o processo analítico ${ }^{6}$.

Dessa forma, a Interpretação/Reinterpretação é um momento da análise que se faz na relação entre as análises formal e sócio-histórica, quando se tenta compreender as relações entre a produção, as formas de produção e a interferência do contexto sócio-político na elaboração e permanência da forma simbólica, podendo ser, ainda, um arremate do processo interpretativo.

É certo que nenhuma fonte dá conta, de modo isolado, de compreender um objeto com tantas perspectivas, como é o caso das práticas educativas. Dessa forma, exercitar a HP implica mobilizar outras tantas formas simbólicas além daquela à qual a hermenêutica se dirige mais propriamente: documentos produzidos à época e sobre a época, entrevistas, cartas, fotografias, regulamentações educacionais, depoimentos de alunos, professores e diretores que utilizaram os manuais, pois os livros didáticos "são produzidos para atender a diversos interesses, como os das editoras, os das novas teorias educacionais, os dos públicos a que são destinados, das políticas educacionais etc. e uma análise que negligencie esses contextos, segundo as diretrizes indicadas por Thompson, torna-se lacunar" (OLIVEIRA, 2008, p.37).

\footnotetext{
${ }^{6}$ Essa afirmação justifica termos optado por colocar entre aspas os termos "terceiro" e "anteriores".
} 
Dentre outros documentos, o prefácio da obra, por exemplo, apesar de ser um dos elementos internos da obra (e objeto da análise formal), também pode contribuir com a análise sócio-histórica, pois revela algumas peculiaridades da época em que o livro foi produzido. De acordo com Genette (2009), os prefácios "[...] multiplicam-se de edição para edição e levam em conta uma historicidade mais empírica" (p.145).

Oliveira (2008) nos apresenta outros fatores que influenciam na elaboração do livro didático e que podem contribuir para a constituição de diferentes versões históricas como "[...] as contraposições, as defesas e acusações, as divergências de concepções e mesmo a defesa de interesses particulares [...]" (p.68). Para que tais informações sejam obtidas, consideramos pertinente o uso de entrevistas com personagens que participaram do processo de produção, adaptação e mobilização da forma simbólica em análise. Nosso exercício de interpretação ao Matemática - curso ginasial teve como apoio, além dos vários depoimentos de professores atuantes à época, entrevistas com os dois tradutores ${ }^{7}$ : a do professor Lafayette de Moraes, cedida a Francisco Oliveira Filho ${ }^{8}$; e a da professora Lydia Lamparelli, disponível em Souza (2005).

Uma última mas não menos importante consideração acerca dos procedimentos metodológicos mobilizados para a análise que este artigo pretende apresentar: a coleção Matemática - curso Colegial, do mesmo SMSG, é dividida em três volumes. Em sua entrevista, o professor Lafayette afirma que a coletânea destinada ao Ginásio ${ }^{9}$ é composta por quatro volumes. O quarto tomo, entretanto, não foi por nós encontrado embora tenham sido intensas nossas procuras em diversos acervos - particulares e públicos - tanto quanto foram inúmeras as consultas feitas a especialistas em História da Educação Matemática e professores da época. Note-se que também foi relativamente difícil encontrarmos o terceiro volume da coleção (se considerarmos a facilidade para obtenção dos dois primeiros tomos e dos três volumes referentes ao curso colegial). Acreditamos que a dificuldade para encontrar os dois últimos volumes da coleção pode ser um indicativo de que ela não obteve o sucesso esperado. É possível que os dois primeiros volumes tenham, de alguma forma, sido "testados" pelos professores e que eles tenham optado por não utilizar os dois últimos volumes da obra nas duas últimas séries ginasiais, já que a experimentação pedagógica - com materiais vários, incluindo dentre eles os livros didáticos - foi uma das diretrizes do ideário Matemática Moderna, ao qual a coleção, ao seu modo, responde. Se foi esse o caso, a indisponibilidade desses dois últimos volumes pode ser resultado da circulação limitada da coleção no Brasil em decorrência da não utilização desses livros. Essa possibilidade torna-se plausível quando constatamos que é bastante

\footnotetext{
7 Moraes e Lamparelli estão registrados, na edição, como tradutores. Sabe-se, entretanto, (Oliveira Filho, 2009; Souza, 2005) que ambos não traduziram literalmente os originais, mas fizeram neles adaptações de acordo com as necessidades do ensino brasileiro. Assim, consideramos como autores da edição brasileira os que elaboraram os originais e seus tradutores para a língua portuguesa.

8 Para seu trabalho de mestrado, Oliveira Filho entrevistou o professor Lafayette mas não disponibilizou, em sua dissertação, a íntegra da entrevista. Tendo ele gentilmente nos cedido as fitas gravadas, textualizamos a entrevista segundo os procedimentos da História Oral e essa textualização, checada pelo depoente, foi disponibilizada integralmente em Silva (2013), com a autorização do entrevistado.

${ }^{9}$ Na seriação escolar da época, o ginásio era composto por quatro anos e sucedia o ensino primário. Com a Lei de Diretrizes e Bases de 1971, o primário e ginásio se fundiram, formando o $1^{\circ} \mathrm{grau}$, atual Ensino Fundamental.
} 
comum ainda hoje encontrarmos, no comércio livreiro, os três volumes da mesma coleção relativos ao ensino colegial, muito utilizados à época nas escolas ${ }^{10}$. Deve-se também considerar que as obras relacionadas à Matemática Moderna produzidas no Brasil para o Ginásio - por exemplo, os livros de Osvaldo Sangiorgi - eram bastante divulgados, e produzidos em grandes tiragens. A disputa de mercado para este nível de ensino - ao contrário do que ocorria para o Colégio - era, portanto, considerável, o que pode ter implicado o fracasso de vendas da coleção para o Ginásio. Ainda que tenhamos consultado frequentemente os três volumes disponíveis para esse exercício de análise, focamos com mais ênfase o primeiro deles. Essa opção exige uma última consideração.

No prefácio da edição brasileira, Lafayette de Moraes busca ressaltar as características essenciais da obra, como um todo, e dos conteúdos, em particular, explorados em cada volume. Ressalta os investimentos do IBECC ${ }^{11}$ relativos à tradução da coleção dedicada ao ginásio, e afirma que eles se devem à acolhida que a coleção do colégio teve no país. Entretanto, inicialmente, seriam dedicados esforços apenas para a tradução do primeiro volume do nível ginasial ${ }^{12}$. Essa afirmação/informação do professor Lafayette, registrada no Prólogo da coleção, teve uma importante implicação metodológica para o trabalho no qual este artigo está baseado: além da perspectiva de experimentação pedagógica que acompanhou parte das iniciativas de implantação e divulgação do ideário do Movimento Matemática Moderna, deve-se ressaltar o sentido de "completude" do primeiro livro dessa coleção para o Ginásio que, segundo as informações do tradutor, serviriam para "representar" a coleção toda no que diz respeito a sua estrutura, a sua organização, seu estilo textual, aos tipos de exercícios propostos, à forma gráfica etc. Concebida, portanto, como "representando" uma iniciativa que se completaria posteriormente com mais três volumes, o primeiro desses volumes seria desenvolvido para testar o alcance (didático e pedagógico, mas também, certamente, as potencialidades mercadológicas) desse conjunto de textos. Portanto, analisar "apenas" um dos volumes - o primeiro -, como propomos neste artigo, é analisar um "exemplo exemplar" que, segundo o próprio idealizador da tradução afirma, representa as potencialidades, as marcas e a natureza de toda a coleção.

\section{Um exercício: a coleção Matemática - curso ginasial, do SMSG}

Cada um dos volumes da coleção do Ginásio tem três textos introdutórios: um Prólogo, o Prefácio da edição norte americana e o Prefácio da edição brasileira. O prefácio da edição brasileira é o único em que a redação foi alterada de um tomo a outro, tendo em vista que seu objetivo é ressaltar as particularidades de cada volume.

\footnotetext{
${ }^{10}$ Lafayette de Moraes ressalta, no prefácio da edição brasileira, que as obras destinadas ao Ginásio foram traduzidas para o português devido a aceitação e acolhida das obras do Colégio.

${ }^{11}$ Criado em 1946, vinculado à UNESCO (Organização das Nações Unidas para a Educação, a Ciência e a Cultura) e resultado de uma coalizão de cientistas e educadores brasileiros, o IBECC (Instituto Brasileiro de Educação, Ciência e Cultura) surge num momento em que cada vez mais a educação científica se impunha como necessária ao desenvolvimento. Coube ao IBECC a tradução do material do SMSG para o português.

12 "/.../ desta vez [isto é, ao contrário do que ocorreu com a publicação dos livros para o Colegial nota nossa] nos restringimos apenas a um volume, o Volume I do Mathematics for Junior High School, porque ele corresponde à primeira série do Curso Ginasial" (SMSG, p. VIII).
} 
Os livros são divididos em capítulos: o primeiro volume da coleção é composto por oito capítulos distribuídos em 311 páginas. As 226 páginas do segundo volume são divididas em seis capítulos que continuam a numeração do volume anterior (de nove a quatorze). Lafayette afirma que os dois primeiros livros da coleção abordam os temas destinados à primeira metade do curso ginasial, sendo, portanto, essa a justificativa para a continuidade da numeração dos capítulos. O terceiro volume contém 271 páginas divididas seis capítulos (numerados de um a seis). Todos os capítulos são subdivididos em tópicos. Ao final de cada tópico é apresentada uma lista de exercícios sobre os temas estudados. Alguns desses exercícios envolvem questões relativas a conteúdos vistos em tópicos e/ou capítulos anteriores. De acordo com o tradutor, os volumes da coleção foram elaborados sequencialmente, visando a organizar os estudos de acordo com a ordem proposta pelos autores, pois um conteúdo sempre se refere a outro previamente abordado na coleção.

Saber que um livro foi produzido pelo grupo norte-americano denominado SMSG, em meados da década de 1960, implica algumas relações e interpretações que, talvez, não fossem feitas de início se esse dado não fosse conhecido. Nesse caso, por exemplo, se o leitor tiver conhecimento sobre alguns dos ideais do SMSG, relacionará a obra ao Movimento Matemática Moderna. Assim é que, concordando com Genette, toda informação, todo paratexto, impõe, já, um viés de análise, um caminho de/para compreensões, uma predisposição.

Uma tradução pressupõe uma interpretação e, portanto, as intenções dos tradutores estão também registradas, de um modo ou outro, menos ou mais explicitamente, na obra publicada. Dessa forma, durante nossas análises, além do grupo de estudos que elaborou o livro, consideramos como autores da coleção os professores Lafayette de Moraes e Lydia Lamparelli que traduziram e adaptaram a obra para o Brasil. Vale ressaltar, porém, que apesar de no primeiro volume da coleção Lamparelli constar como tradutora, seu nome não é mencionado nos dois volumes seguintes. Nas edições para o Colégio a professora assina as traduções de todos os volumes, juntamente com o professor Lafayette. Neles, Lamparelli assina, inclusive, o prefácio da edição brasileira, o que não ocorre nos livros do Ginásio.

Dos paratextos indicados por Genette, ressaltemos a composição gráfica dos volumes. As capas das coleções publicadas pelo SMSG são, em geral, compostas por duas cores. Nas do Ginásio, o roxo e o amarelo, nas do Colégio dois tons de vermelho. As inscrições da capa seguem as cores de fundo, com algumas palavras sombreadas, com a intenção de destacá-las. Entendemos que as poucas cores e destaques na capa da coleção deixam a obra com um aspecto clean, sofisticado, sendo esse um fator que poderia contribuir para promover a "modernidade" do texto e do seu conteúdo: uma modernidade "sóbria". Do ponto de vista financeiro, o uso de poucas cores ou de motivos diferentes de uma mesma cor torna a produção mais barata, embora esse fator aparentemente não seja determinante para a diagramação da obra, posto que os investimentos editoriais em livros dessa natureza, com vendas significativas e tiragens enormes, podiam dispensar tal economia. $O$ design das capas das coleções do SMSG - e das capas de todas as coleções produzidas por grupos similares - como as coleções de Física (produzida pelo Physical Science Study Committee), de Biologia (produzida pelo Biological Science Study Committee) e o de Química (produzido pelo Chemical Bond Approach (omittee) - seguem um mesmo padrão que poderia ainda hoje ser visto como esteticamente atual: poucas cores, espaços amplos sem texto, figuras e grafismos "dinâmicos" e de traçado econômico, esboçando temas próprios da área para a qual os livros se dirigiam - gráficos de movimento nos livros de Física, parábolas nos de Matemática, vidraria de laboratório nos de Química, estruturas do DNA nos de Biologia etc. 
A maioria dos livros brasileiros de Matemática contemporâneos às coleções do SMSG tinha design bastante colorido e alguns deles eram bastante saturados de informação (figuras e textos). A sobriedade moderna das capas do SMSG destoa, portanto, das demais capas dos livros produzidos à mesma época, e mantém-se "esteticamente agradável" ainda hoje, ao passo que as capas de boa parte da produção didática brasileira da época parece ter ficado datada, ultrapassada.

Na capa há referência clara ao grupo que elaborou o texto (School Mathematics Study Group), ao título da coleção (Matemática), ao nível para o qual a obra é destinada (Curso Ginasial) e à editora brasileira (EDART - Livraria Editora Ltda. - S. Paulo). Além da sigla há o símbolo da editora. Há, também, três figuras geométricas seccionadas por um plano. A mesma figura é apresentada nos demais livros do curso ginasial e nos livros destinados ao Colégio, o que dá unidade visual às coleções voltadas para o ensino de matemática (o mesmo ocorre com as coleções das demais áreas). O uso de figuras geométricas como recurso para associar um livro didático à Matemática é comum ainda hoje nas capas de livros dessa disciplina escolar, como era também, inclusive, à época em que os livros foram publicados. Vale destacar que nas capas não é feita menção aos nomes dos tradutores brasileiros.

O miolo do livro inicia-se com a folha de rosto que contém o título da obra, o nível para o qual é destinada e o volume da coleção. No verso dessa primeira página há informaç̃os sobre o endereço da editora e a indicação de seus diretores editoriais (Artur Neves e Washington Helou). Na contracapa e em seu verso há informações sobre o texto original e dados sobre a tradução: a coleção original, intitulada Mathematics for Junior High School, foi publicada pela Yale University Press de New Haven, EUA. Organizada pelo School Mathematics Study Group, as obras tiveram os direitos editoriais cedidos à EDART, Livraria de São Paulo. Autorizada pelo IBECC-UNESCO, a tradução da edição preliminar para o português foi realizada pelos Professores Lafayette de Moraes e Lydia Lampareli e datilografada por Marianina Malvezz, sendo publicada, no Brasil, em 1967.

Valente (2008) destaca que o professor Sangiorgi caracteriza como "preliminar" um de seus livros publicados ${ }^{13}$ para o Colégio posto tal edição ter sido produzida na esteira do sucesso das suas obras destinadas ao Ginásio e em atenção à solicitação dos professores. Com o selo "edição preliminar" da coleção do SMSG os autores destacam tratar-se da primeira tradução das obras destinadas a esse nível de escolaridade, como que iniciando um processo de experimentação pedagógica que levaria, se necessário, a revisões e adaptações (o que acabou não ocorrendo devido à pequena circulação e pouca influência da coleção).

O título da coleção - Matemática - e o registro da seriação - Ginásio - como subtítulo apontam de forma clara e objetiva a disciplina e o nível para o qual a obra era destinada. Os livros didáticos de matemática publicados à década de 1960, em sua maioria, continham o termo "moderno" em seu título, muitas vezes com a função de ressaltar um aspecto "desejável" - uma contraposição ostensiva a "antigo", "velho", "ultrapassado" -, que servia

13 A produção de Sangiori para o Colégio não teve muita repercussão, principalmente se considerarmos o sucesso de suas obras para o Ginásio. Com a coleção do SMSG para o ginásio ocorreu um fracasso inverso, mas de mesma natureza: o Matemática - Curso Ginasial, produção aparentemente malfadada do ponto de vista comercial, também foi produzido devido ao sucesso das obras do grupo para o Colégio. 
para o marketing e a propaganda. O SMSG não inclui o adjetivo "moderno" em seus títulos, mas deve-se ressaltar que, à época em que os originais foram produzidos, o movimento de renovação do ensino de matemática ainda não era conhecido por Movimento Matemática Moderna, embora a expressão "New Math" já circulasse. De outra feita, entretanto, a própria menção explícita ao SMSG supria essa referência (ao novo e ao moderno), tendo sido o grupo especificamente constituído com a intenção de promover e divulgar um ideário, diferentemente do que ocorria com autores brasileiros, muitos deles já conhecidos no mercado editorial e tendo já produzido livros-texto sem vinculação a um ideário específico ou vinculados a outro ideário que não esse que, aos poucos, se tornava hegemônico no que diz respeito ao mercado editorial. Assim, "SMSG" é sigla que agrega vários elementos, dentre os quais o adjetivo "moderno/novo" que caracterizaria a nova abordagem para a sala de aula. Aos autores brasileiros da época, restava propagandear o adjetivo "moderno" aos títulos, com o que inscreviam suas obras - e a si próprios - como seguindo uma tendência nova e contrária às abordagens tradicionais vigentes no ensino de Matemática.

O Prólogo tem como intuito apresentar os objetivos do SMSG e aspectos relativos à sua criação, bem como defender a importância da melhoria do currículo de matemática vigente à época. Financiado pela National Science Foundation (NSF) e formado por matemáticos e educadores (matemáticos), o SMSG surgiu com o objetivo de aperfeiçoar o ensino da matemática nas escolas secundárias. Para tanto, o grupo defendia que esse ensino deveria levar em consideração as aplicações da matemática em outros campos do conhecimento, propiciando, assim, reflexões sobre os avanços dessas ciências e os da própria matemática. No prólogo são ainda levantados alguns pontos sobre o modo como a matemática é vista e, em decorrência, como os conteúdos são tratados na coleção. Segundo os autores, a "forma" com que tais conteúdos são apresentados permite a rápida compreensão pelos alunos. Além disso, ressaltam que apenas alguns conteúdos propostos são novos, a maioria deles é familiar, já presentes no currículo tradicional, sendo apenas tratados sob outros pontos de vista nas obras publicadas pelo grupo. Essa forma de apresentação, mesclando conteúdos ditos tradicionais a conteúdos novos, tem como objetivo mostrar que a matemática não é um patrimônio morto que nos foi legado, mas uma ciência viva e em constante transformação. Além disso, essa apreensão possibilitaria aos alunos compreenderem de forma mais detalhada os conteúdos básicos. Os autores finalizam o Prólogo afirmando que a obra não é o caminho para o sucesso do ensino de matemática, mas uma amostra do tipo de currículo que a sociedade da época necessitava. Afirmam, por fim, desejar que as obras inspirem um ensino mais significativo da matemática, "rainha e escrava das Ciências".

O prefácio da edição norte americana apresenta o processo de elaboração dos livros em suas versões na língua inglesa. Inicialmente foram elaboradas catorze unidades experimentais, para o $7^{\circ}$ e $8^{\circ}$ graus, que após serem testadas por 100 professores, entre 1958 e 1959, passaram por uma revisão no verão de 1959. A partir dessas revisões foi apresentado um novo modelo para o $7^{\circ}$ grau e elaborados novos livros para $08^{\circ}$, estes pré-avaliados por 175 professores, revistos no verão de 1960, e publicados no mesmo ano. Essa iniciativa de "experimentação pedagógica", à qual já nos referimos, é bastante marcada no Movimento Matemática Moderna. Não se trata apenas de produzir e divulgar livros e outros materiais escolares: trata-se de produzi-los e, antes de divulgá-los comercialmente, aplicá-los em classes experimentais. No Brasil, por exemplo, a professora Marta Dantas, da Bahia, seguiu estritamente essa proposta das "experimentações pedagógicas". 
A coleção americana, ainda segundo o Prefácio traduzido, foi elaborada de acordo com conteúdos e conceitos julgados importantes e necessários para o primeiro ciclo do curso secundário: o tratamento da estrutura Aritmética, o cuidado com o ponto de vista algébrico, o sistema dos números reais e as relações métricas e não métricas na Geometria. Ressalta-se também o fascínio que a matemática pode despertar tanto por sua possibilidade de criar e descobrir quanto por sua utilidade, digamos, "prática". Os alunos das séries às quais os livros se destinam são vistos como tendo potencial para formular questões matemáticas e levantar hipóteses, podendo, inclusive, desenvolver processos para solucionar problemas. Esses fatores são alguns dos pontos considerados, segundo os autores, para a seleção dos conteúdos e da metodologia propostos.

No Prefácio da edição brasileira, o tradutor ressalta a opção de tradutores e editores por reproduzir o texto de acordo com original, ficando os cortes e as adaptações, se julgadas necessárias, a cargo do professor, ainda que em entrevista o mesmo tradutor afirma terem sido tomadas certas "liberdades" no processo de tradução de modo a adaptar o original americano para o sistema de ensino brasileiro, como se vê também na continuidade deste mesmo Prefácio. Referindo-se ao estudo dos sistemas e bases de numeração, o tradutor afirma o nível de exigência relativo a este tópico pode ser considerado elevado, ficando a critério do professor abordá-los ou não. Quanto ao tópico referente às unidades de medidas, afirma que foram realizadas algumas modificações com relação aos originais, do que decorreu a inclusão até mesmo de um estudo sobre as unidades inglesas, devido à sua aplicabilidade na vida prática. Com relação aos exercícios, Lafayette os classifica em três categorias: os de "aplicação da teoria"; os que "apresentam dificuldade maior" e os "Problemas-Desafio", que são vistos como uma complementação. Identificamos, porém, outras duas classificações para os exercícios propostos: os de "revisão" e as "atividades para discussão em classe".

O leitor entenderá a dificuldade de reproduzir, neste artigo, a análise formal realizada no estudo da coleção. Entretanto, algumas considerações resultantes dessa análise devem ser explicitadas.

Uma das características essenciais notadas na análise da obra refere-se a sua abordagem que, embora sequencial, se vale constantemente da retomada de conteúdos já vistos para o estudo de novos conceitos. Além da relação entre os tópicos matemáticos, são ressaltadas as relações entre conceitos matemáticos "novos" e "antigos", mobilizando a História da Matemática, o que serve para mostrar que a matemática se transforma com o correr do tempo. Também há relações entre a Matemática e diferentes áreas do conhecimento, o que, além de ser uma abordagem mantida nos manuais mais recentes, serve de exemplo às potenciais aplicações da Matemática e seu papel de "interlocutora" no conjunto das ciências.

Em vários momentos do texto os autores ressaltam a importância da matemática no desenvolvimento das novas tecnologias e na formação dos profissionais de diferentes áreas. Nesse sentido, é significativo o destaque dado às pesquisas relacionadas às viagens espaciais. Segundo os autores, "todo projeto novo na indústria de aviação, em viagem espacial ou em eletrônica requer maior especialização dos engenheiros, cientistas e técnicos". (p.11). No período em que as obras originais, em língua inglesa, foram produzidas, estava em evidência o lançamento de dois satélites artificiais para o espaço, os Sputniks I e II. Esses acontecimentos são evidenciados pelos autores, que afirmam vivermos, à época, na "Era Espacial" (p.97). 
Outro ponto que vale destacar é o incentivo dado pelos autores, nos exercícios, perguntas e curiosidades, para que os alunos realizem "pesquisas" para compreender melhor alguns pontos estudados. A procura por essas informações em enciclopédias, almanaques, jornais, dentre outros meios sugeridos, permite que os alunos não só busquem atualizar-se e aprofundar-se sobre o tema proposto, indo além do manual escolar, como também encontrem outras informações que possam ser úteis a eles em outros momentos e contextos.

Algumas proposições, propriedades e fórmulas matemáticas devem ser "deduzidas" pelos alunos. Além disso, eles devem mostrar, em alguns casos, que certas propriedades são válidas. Essa forma de trabalhar com os conteúdos é interessante, mas entende-se que deve ser mobilizada com cautela, pois as atividades parecem difíceis para o nível de ensino ao qual o livro é destinado. Essa dificuldade talvez fosse detectada também entre os professores, que em muitos casos não haviam frequentado cursos superiores de Matemática ou outras instâncias de formação nas quais uma abordagem dessa natureza era problematizada ou sequer sugerida.

As propriedades e resultados são, inicialmente, abordados por meio de desenhos e/ou exemplos numéricos para, em seguida, serem generalizados. Em alguns momentos tais generalizações são propostas como exercícios aos estudantes.

Outro fator que, segundo as disposições dos livros, pode auxiliar na formação dos conceitos matemáticos é a apresentação do desenvolvimento histórico dos conteúdos. Em vários momentos, os autores recorrem à história da matemática para explicar como os resultados apresentados se desenvolveram. Essa proposta de abordagem histórica pode ser percebida, por exemplo, na seção relativa aos sistemas de numeração (quando são apresentados desde os sistemas dos povos antigos até o atual); na seção dedicada ao estudo dos números naturais (quando são destacadas as relações usadas antigamente, quando os numerais ainda não existiam); no trabalho com as unidades de medidas (quando é realçada a importância das unidades padrão devido à sua utilidade e às dificuldades encontradas pelos comerciantes quando ainda não havia uma "unificação" ${ }^{14}$; no tópico relativo aos números racionais (que se inicia com aspectos da história das frações). Os autores também demonstram preocupação com a aprendizagem dos conceitos e com suas operacionalizações nas várias revisões e resumos apresentados no decorrer dos capítulos. No final de cada capítulo é apresentado um resumo dos conteúdos nele discutidos. Além dessas sínteses, em alguns momentos, são propostos exercícios de revisão dos conteúdos já vistos.

${ }^{14}$ Deve-se notar, nesse sentido, que embora essa abordagem ao tema da padronização dos sistemas de medida seja, digamos, ultrapassada, ela é ainda hoje bastante comum nos livros didáticos, inclusive em manuais aprovados pelo PNLD. Os pesquisadores em Etnomatemática, por exemplo, são os primeiros a ressaltar o equívoco dessa abordagem segundo a qual a inexistência de um padrão implicou uma padronização acatada ágil e docemente pela população. Sabe-se que a aceitação do sistema métrico não foi ampla (os Estados Unidos, por exemplo, não incorporaram esse sistema de medida até hoje), nem imediata (mesmo no Brasil, que adotou o sistema, essa adoção ocorreu no momento de internacionalização do sistema - por volta dos anos de 1870 - tendo sido proposto na França no final do século XVIII), nem pacífica (o exemplo emblemático é o da Revolta do Quebra-quilos, ocorrida no Nordeste, a partir da Paraíba, em 1874). 
Um dos diferenciais do livro com relação a outras obras destinadas para o mesmo nível de ensino, no que diz respeito ao conteúdo, é a opção por uma abordagem de alguns tópicos a partir do conceito de "conjunto", ainda que essa opção não seja tão sintomática como suporíamos ao considerar o livro como um dos precursores na divulgação do Movimento Matemática Moderna. Cumpre ressaltar ainda, que, segundo nossa perspectiva, os autores utilizam uma linguagem simples, seja ela a linguagem usual - da língua corrente - ou a linguagem matemática. Além disso, sempre que novos símbolos ou termos são introduzidos, são ressaltados seu significado e a importância do seu uso.

Como um exercício paralelo de análise, procedemos à avaliação desse primeiro volume considerando os critérios atualmente utilizados para a avaliação dos livros atuais pelo PNLD (Programa Nacional do Livro Didático $)^{15}$. Percebemos a possibilidade (e, talvez, a importância) de proceder a essa comparação ao notarmos que o livro sob análise nos pareceu bastante similar, em vários aspectos, aos atuais livros de Matemática para os 50, $6^{\circ}$, $7^{\circ}, 8^{\circ}$ e $9^{\circ}$ anos da escolarização atual (equivalentes ao antigo Ginásio). Essa "atualidade da obra" diz respeito não somente aos tópicos do Programa, mas também à forma de abordálos. Em vários aspectos esse livro se diferencia do que se tem tomado como "modelo" para os livros de Matemática produzidos sob a égide do Movimento Matemática Moderna: a simbologia é usada de modo econômico; não se percebe o enfoque hegemônico da teoria dos conjuntos que se diz caracterizar os livros "do Movimento"; os exercícios são diversificados e criativos; as explicações pautam-se, em boa parte das vezes, em exemplificações do mundo cotidiano e das práticas diárias nas quais a Matemática está envolvida; ainda que haja formalização, ela é introduzida contextualizadamente e não de modo precoce etc. Posto isso, julgamos interessante esse exercício de avaliar esse primeiro volume da Coleção à luz de alguns dos parâmetros que têm servido para o PNLD analisar os livros atuais de Matemática. Desse exercício, dentre outros pontos, destacamos que (a) a coleção é articulada em seus volumes, explicitando vínculos entre conteúdos e conceitos; (b) além da articulação entre conceitos, algoritmos e procedimentos, percebe-se uma homogeneidade no tratamento desses itens no que se refere à linguagem; (c) cada conteúdo é introduzido a partir da apresentação de um (ou alguns) exemplo(s), ao que se seguem uma sistematização e uma atividade de aplicação; (d) valorizam-se os conhecimentos cotidianos e as experiências dos estudantes extraclasse; (e) em todo o texto há um cuidado contínuo para favorecer competências complexas como observar, explorar e investigar, generalizar, questionar, argumentar e tomar decisões, visualizar, expressar e registrar ideias e procedimentos; (f) apresentam-se desafios e problemas sem solução; (g) são utilizadas diferentes estratégias na resolução de problemas; (h) o manual valoriza o desenvolvimento de habilidades como o cálculo mental e o cálculo por estimativa; (i) os conhecimentos matemáticos são contextualizados com relação à história da matemática, às práticas sociais da época e a outras áreas de conhecimento; (j) a língua materna é adequadamente cuidada, pertinente, sem afetações ou exageros, o uso da linguagem

${ }^{15}$ O PNLD, instituído em 1985, estabelece critérios para a avaliação dos livros didáticos brasileiros. De acordo com Carvalho (2008) o processo de avaliação das obras, inicia-se, porém, em 1997. O PNLD, atualmente vigente, é uma versão de outras estratégias para avaliação de materiais didáticos que, no Brasil, têm sido efetivadas desde a década de 1930. Para nossa avaliação da Coleção, seguindo os parâmetros contemporâneos estabelecidos pelo PNLD, utilizamos as indicações do Guia do Livro Didático do ano de 2010. 
matemática; (k) a estrutura da coleção é hierarquizada e essa hierarquia é explícita (em títulos, subtítulos etc.); e, finalmente, (I) a coleção apresenta um sumário que auxilia na localização dos assuntos e seus tópicos e subtópicos são bem distribuidos e claramente indicados.

\section{Breve panorama de uma longa década}

Na década de 1960 houve um grande desenvolvimento econômico e tecnológico tanto nos países capitalistas como nos socialistas. Esse crescimento pode ser notado por meio dos diferentes benefícios proporcionados à população, como a energia barata e o acesso a inovações (principalmente as eletrônicas e eletroeletrônicas). Os avanços tecnológicos são percebidos, porém, desde a Segunda Guerra Mundial, sobretudo pelas avançadas máquinas de guerra alemãs. De acordo com Hobsbawm (1998),

A guerra, com suas demandas de alta tecnologia, preparou vários processos revolucionários para posterior uso civil, embora um pouco mais do lado britânico (depois assumido pelos EUA) que entre alemães com seu espírito científico: radar, motor a jato e várias idéias e técnicas que prepararam o terreno para a eletrônica e a tecnologia de informação do pós-guerra. (p. 260).

Após a Segunda Guerra, as grandes potências mundiais passaram por outro momento de crise, a Guerra Fria, com soviéticos e americanos desempenhando, nesse cenário, os principais papéis. Além da busca por uma hegemonia política e econômica, nesse período houve também uma disputa quanto aos avanços espaciais. Inicialmente, o mérito pelo desenvolvimento espacial foi dado à URSS, que lançou, em outubro de 1957, o primeiro satélite espacial russo, o Sputnik I.

No Brasil também se nota um considerável avanço durante a década de 1960, resultado lento de ações e políticas desenvolvidas desde o período colonial. Se no Brasil colônia o país teve como principal atividade econômica a agricultura, o processo de industrialização começou a ser incentivado e desenvolvido principalmente a partir da política de governo de Getúlio Vargas, chegando à de Juscelino Kubistchek. Durante o governo de Café Filho (empossado após o suicídio de Getúlio e enfrentando uma presidência marcada por grande instabilidade), a política cambial passou a favorecer a importação de equipamentos por investidores estrangeiros, sendo o capital adquirido com essas importações a principal fonte para a implantação do setor de produção de bens duráveis, como a siderurgia, que avançou consideravelmente já no governo seguinte, o de Juscelino. A Usina de Volta Redonda, a Companhia Vale do Rio Doce e a Petrobrás, essenciais para o desenvolvimento industrial do país, haviam sido gestadas ainda no governo Vargas. Essas conquistas, entretanto, ganharam maior dimensão durante 0 governo de Kubistchek, com a criação de medidas alfandegárias que possibilitaram a vinda de empresas internacionais para o Brasil, como a Volkswagen. O avanço tecnológico e o desenvolvimento industrial provocaram mudanças na educação, posto que com a introdução e desenvolvimento de novas tecnologias era preciso que os cidadãos tivessem maior conhecimento em ciências e matemática, além de um maior domínio técnico, o que provocou, em consequência, mudanças no ensino. O aumento na expectativa de vida e a diminuição das horas de trabalho também foram consequências desse desenvolvimento. De acordo com Búrigo (1989), na década de 1950-1960 havia "um modo de pensar social que 
atribuía à ciência e à tecnologia a capacidade ilimitada de incrementar a qualidade de vida e bem-estar social" (p. 50).

Esses avanços, bem como os resquícios da Segunda Guerra Mundial e da Guerra Fria, marcaram mundialmente a década de 1960: crivada por transformações propostas pelos jovens, que organizaram vários manifestos, deu-se relevo à defesa de uma vida simples em que imperasse a igualdade; o movimento hippie, com o lema "paz e amor", ganhou reconhecimento e arregimentou vários seguidores. O rock, por sua vez, era fonte de inspiração do comportamento da juventude, sendo, além de música, um modo de viver, uma "atitude". No Brasil, a Bossa Nova cria a noção de juventude como hoje a concebemos. Os protestos dos jovens franceses, em 1968, em busca por melhorias no ensino, considerado por eles como arcaico e conservador, criticavam a sociedade e a política da época. Tendo recebido o apoio de intelectuais de várias áreas, os protestos de Paris passaram a ser disseminados pelo mundo todo, incentivando jovens de outros países. Com - slogan "É proibido proibir" foi declarada a liberdade sexual e a posição contrária ao poder estabelecido. Interessante notar que, à época, a Matemática escolar, seus programas e o tratamento sugerido aos seus conteúdos, se enrijecem, ao passo que o comportamento social e suas regras se flexibilizam.

O movimento estudantil incentivou, também, a luta por melhorias para a classe operária; os operários, por sua vez, fizeram greves reivindicando melhores salários e condições de trabalho. A Passeata dos Cem Mil, no Rio de Janeiro, em 1968, é considerada um dos movimentos mais importantes contra o regime militar ${ }^{16}$ : mostrava-se publicamente o descontentamento com o gerenciamento do Estado e, particularmente, cobrava-se uma atitude do governo com relação aos problemas estudantis. A polícia reagia de forma agressiva às passeatas promovidas, principalmente, por estudantes secundaristas e universitários, causando mais revolta e trazendo novos aliados aos movimentos, dentre eles artistas, professores e religiosos. (PILAGALLO, 2009). Os manifestos organizados pelos estudantes reivindicavam mais verbas, vagas e melhores condições de ensino nas universidades públicas. Além das melhorias na educação, os jovens também lutavam pela liberdade democrática e se opunham ao estado militarizado. Devido às ações que liderava, o movimento estudantil desse período teve grande importância na mobilização social da época.

Com a ditadura, alguns dos movimentos educacionais então vigentes foram extintos. Em contrapartida, outros foram criados, dentre eles o MOBRAL (Movimento Brasileiro de Alfabetização) em $1967^{17}$. Em 1968, a Reforma Universitária ${ }^{18}$ propôs a expansão ${ }^{19}$ e modernização das universidades federais, essenciais para a democratização do ensino.

${ }^{16}$ Iniciado em 1964, no Governo Castello Branco (1964-1967), com a promulgação dos primeiros Atos Institucionais (AIs), manteve-se sob a liderança de Costa e Silva (1967-1969), Garrastazu Médici (1969-1974), Geisel (1974-1979, quando se inicia o movimento de abertura) e Figueiredo (19791985). O Regime Militar será proclamado extinto em 1985. Eleições presidenciais com candidatos civis, realizadas em 1984, levaram à elaboração e aprovação de uma nova Constituição em 1988.

${ }^{17}$ Com o objetivo de alfabetizar jovens e adultos, o projeto Movimento Brasileiro de Alfabetização (MOBRAL), criado pela Lei 5.379/67, ficou em vigência no Brasil por aproximadamente 18 anos, sendo extinto em meados da década de 1980. Já que nestre trabalho tratamos de apropriações e mobilizações, é interessante registrar que, de acordo com Jarbas Passarinho, em entrevista à Buffa e Nosella (1997), o MOBRAL foi obra sua, porém, quando foi para o senado, as diretrizes do projeto 
A educação básica também sofreu transformações nesse período. Durante as décadas de 1940 e 1950 houve um aumento considerável no número de estudantes do ensino secundário, acarretando no crescimento da rede pública de ensino e provocando debates sobre a criação de redes particulares de ensino. A Lei de Diretrizes e Bases (LDB/4024), aprovada pelo governo João Goulart, em 1961, regulamentou o ensino no Brasil, e foi autorizada a criação de escolas no setor privado. A estrutura do ensino, por sua vez, não sofreu alterações, permanecendo da mesma forma como havia sido estipulada pela Reforma Capanema, ou seja, foram mantidos - com pouquíssimas alterações além da nomenclatura - os quatro níveis de escolaridade: pré-primário, primário, ensino médio (dividido entre ginásio e colégio) e superior.

De acordo com Lavorente (2008), a LDB de 1961 foi criada com o intuito principal de descentralizar o sistema educacional do país. Assim, o Colégio Pedro II, até então padrão para as demais escolas, deixa de ser modelo no ensino e cada estado fica responsável por estabelecer o currículo de suas instituições. Embora não existisse mais a obrigatoriedade de seguir o Pedro II, de acordo com Lavorente, os Estados continuavam a utilizá-lo como referência, devido sua tradição ${ }^{20}$.

Na década de 1960, a formação inicial de professores era feita em Curso Normal, para professores que pretendiam lecionar para o ensino primário, e em cursos superiores, que formavam professores para o secundário. A formação desses professores era dada, principalmente, pelas Faculdades de Filosofia Ciências e Letras (FFCL), que ofereciam cursos de licenciaturas para as disciplinas que compunham o currículo escolar. Criadas nos anos de 1930, as FFCL "[...] tinham por objetivo desenvolver estudos livres e a formação de professores secundários, afastando o ensino superior de um modelo de ensino mais profissionalizante [...]" (MARTINS-SALANDIM, 2012, p. 23). A LDB 4024/61 previa que a formação de professores para o ensino médio (ginásio e colégio) deveria ser realizada nessas instituições. Martins-Salandim (2012) ressalta que, na década de 1960, apesar de já extinto oficialmente o modelo de licenciatura " $3+1$ " - os três anos de graduação dedicados ao estudo dos conteúdos matemáticos e o último às disciplinas pedagógicas -, esse sistema ainda permaneceu como estratégia de organização das licenciaturas, sendo, portanto, dada maior ênfase aos conteúdos específicos de matemática em detrimento da parte pedagógica.

foram alteradas, o que implicou seu fracasso. Passarinho - então um dos ministros da Ditadura afirma, ainda, que na elaboração da Proposta, ainda sob sua gestão, foram seguidas as disposições modernas e reformadoras como, por exemplo, a pedagogia de Paulo Freire.

18 A Reforma Universitária, implantada em 1968, tinha como principais objetivos modernizar e expandir as universidades públicas. Apesar dos efeitos inovadores que a reforma obteve no ensino, universidades privadas também se expandiram e ofereceram um ensino que negligenciava a formação de pesquisadores, como propunha a reforma. É resultado dessa reforma a departamentalização das Instituições de ensino superior vigente - com raras exceções - até hoje.

19 Dados estatísticos nos ajudam a entender a dimensão das conquistas defendidas pelas manifestações organizadas da época: de 27.253 estudantes em 1945, passou-se para 214 mil matriculados em 1968 (Cancian, 2012).

${ }^{20}$ O recente trabalho de mestrado de Pardim (2013) revela, dentre outros elementos, quão importante eram os livros didáticos para induzir nacionalmente um Programa de Ensino pautado nas disposições das escolas do eixo Rio-São Paulo, mesmo numa época em que o Colégio Pedro II, por exemplo, deixava de ser referência obrigatória para os Programas. 
O parecer n 292, emitido em 1962 pelo Conselho Federal de Educação, previa que os cursos de formação de professores de matemática deveriam conter as disciplinas ministradas no bacharelado e as que habilitavam o profissional para o magistério nas escolas de ensino médio. Assim, além dos conteúdos matemáticos, os cursos de licenciatura deveriam ter disciplinas "pedagógicas" como Psicologia da Educação, Adolescência e Aprendizagem, Didática e Elementos de Administração Escolar e Prática de Ensino. Oliveira, Silva e Valente (2011) e Martins-Salandim (2012) destacam que o número de cursos de matemática nas FFCL, bem como o de professores com curso superior, cresceu no decorrer da década de 1960. Em 1962, havia apenas 13 faculdades com Departamentos de Matemática, já em 1965 esse número aumentou para 46, enquanto o número de professores formados em exercício cresceu de 22\% para 47\% nesse mesmo período. Sabese, entretanto, que, mesmo com esse aumento, a quantidade de professores formados era incipiente para atender à demanda dos cursos secundários então em franca expansão ${ }^{21}$. Além disso, o foco nesse crescimento para representar a situação nacional, diz muito pouco por focar-se no sudeste do país e não atentar para outras regiões - como o Norte, o Nordeste e o Centro-Oeste -, extremamente carentes do ponto de vista de escolarização superior até décadas bem mais recentes.

De acordo com Oliveira, Silva e Valente (2011), apesar do aumento dos cursos e do número professores graduados, a formação inicial desses profissionais era deficiente e problemática. Com o intuito de trazer melhorias, atualização e complemento para os docentes que já atuavam nas redes de ensino foram oferecidos cursos de reciclagem, treinamento e capacitação, em especial nas cidades do Rio de Janeiro e de São Paulo. Os cursos de reciclagem tinham como principal objetivo atualizar o professor, reaproveitando e complementando a sua formação inicial, mas, efetivamente, reiteravam o processo lacunar pelo qual eles já haviam passado, formalizando a situação do professor sem, contudo, contribuir significativamente para sua formação.

\section{Mobilizações/apropriações do Movimento Matemática Moderna}

Os diferentes modos de ver e conceber o que se convencionou chamar de Movimento Matemática Moderna são tema destacado por Souza e Garnica (2013), autores que apresentam três concepções sobre o "mesmo" Movimento. Cada uma dessas concepções pode ser detectada no discurso de diferentes agentes (ou conjunto de atores), ligados ao setor educacional, em atuação à época em que "o" ideário se implantou no Brasil. A esses grupos distintos - cada um deles promovendo discursos legítimos e diversos sobre o que pensavam ser o MMM -, Souza e Garnica chamam de "os gerenciadores", "os professores-multiplicadores" e "os professores em sala de aula". Neste artigo, baseados no pressuposto de que, embora o meio cultural seja marcante, o fator subjetivo é certamente

\footnotetext{
${ }^{21}$ De acordo com Baraldi (2003), a Campanha de Aperfeiçoamento e Difusão do Ensino Secundário (CADES) foi lançada pelo governo federal na década de 1950 com o intuito de aperfeiçoar a formação específica de professores que atuavam em sala de aula. A frequência no curso da CADES tornou-se pré-requisito para os professores que queriam ministrar aulas no ensino secundário mas não tinham disponíveis, em suas regiões de atuação, cursos superiores de formação específica.
} 
determinante no movimento de atribuir significado, é desenvolvido um exercício de aproximação a possíveis significados atribuídos ao MMM por cada um desses três grupos de agentes educacionais bastante distintos. Certamente, focando os sujeitos que constituem esses grupos encontrar-se-iam outras afirmações sobre o Movimento que poderiam plausivelmente ser tomados como significados possíveis ao MMM, já que, no limite, cada um atribui significado segundo seus pressupostos. Os três grupos, portanto, são exemplos exemplares para sustentar a inexistência de UM MMM, e defender a perspectiva da coexistência de inúmeros MMM.

A posição desses grupos constituídos em Souza e Garnica (2013) com relação ao Movimento, seus objetivos e suas concepções sobre o sucesso/fracasso desse ideário (ou o que concebem como sendo o ideário) muitas vezes diferem, podendo ser tanto complementares, como rivais. Analisando documentos disponíveis e criados (a partir de entrevistas) com agentes vinculados a um Grupo Escolar do interior do Estado de São Paulo, os autores voltaram-se a compreender três dentre os distintos e múltiplos significados atribuídos à expressão. O grupo dos gerenciadores é composto por professores e pesquisadores que, ocupando liderança nacional no que diz respeito ao ideário da MMM, à época, estavam mais próximos do ideário internacional e abraçaram a função de divulgá-lo e promovê-lo. O grupo dos professores-multiplicadores é formado por professores e administradores escolares - claramente referenciados nas falas dos professores do Grupo Escolar e em atas de reuniões pedagógicas - que tinham a função de obter informações sobre o MMM (por exemplo, freqüentando cursos e reuniões de aperfeiçoamento ocorridas na cidade de São Paulo e em outras localidades) para esclarecer os professores em efetivo exercício no magistério. Professores em efetivo exercício na escola primária constituem o terceiro grupo cujo discurso de apropriação ao Movimento foi estudado por Souza e Garnica.

Também Búrigo (1989), munida de outros referenciais, ressalta a pluralidade de pontos de vista que coexistiram amalgamadas no que se chama de MMM ao afirmar que "um movimento que reuniu tantos protagonistas, como foi o caso da matemática moderna, não poderia ter professado um discurso homogêneo e coerente em todas as suas manifestações" (p. 36).

Assim, este nosso exercício de análise da obra Matemática - Curso Ginasial, do SMSG, corrobora e colabora com essas afirmações, e defende que essa coleção de livros, ao seu modo, explicita um discurso específico sobre a Matemática Moderna que não é de todo sincrônico com os elementos que usualmente têm servido para caracterizar o Movimento.

Os livros didáticos com os conteúdos e abordagens propostas "pela Matemática Moderna" tiveram, segundo Valente (2008), grande importância na divulgação do Movimento no país e, segundo Soares (2001), o livro didático foi também "responsável em grande parte pelos 'exageros' cometidos em nome da Matemática Moderna" (p. 58).

Não é difícil encontrar, tanto nos trabalhos de pesquisadores sobre o Movimento, quanto no discurso de professores que o vivenciaram no interior dos espaços escolares, a afirmação de que a Matemática Moderna fracassou, que várias de suas ideias iniciais foram "deformadas" ou não efetivamente colocadas em prática 22 e que o ensino da Matemática,

22 É importante notar que o verbo "deformar" implica existir previamente uma forma que será, então, desvirtuada, alterada. O verbo "deformar" insinua, inclusive, uma ação intencional, isto é, conhecendo a forma, opto conscientemente por alterá-la, deformá-la. Assim, a afirmação de que alguns agentes 
por fim, não sofreu a transformação esperada. Como causas principais para este estado de coisas são apontadas tanto a ênfase exagerada na Teoria dos Conjuntos quanto a falta de preparação dos professores.

Não há, entretanto, consenso entre os pesquisadores e professores sobre os acertos e desacertos do MMM. Há versões diferenciadas sobre seus objetivos, sobre seus métodos, sobre sua efetivação, sobre suas falhas, sobre seus sucessos e seu fracasso. Isso legitima nossa leitura, isto é, a interpretação de que o estudo dos pontos de vista atualmente disponíveis sobre o ideário exige que, para uma avaliação global, se aposte mais na ideia de uma multiplicidade de abordagens e apropriações do MMM do que numa versão definitiva e unívoca. Assim, o uso do singular (o Movimento), deveria ceder lugar ao plural (os Movimentos Matemática Moderna).

\section{Conclusão em retomadas}

De acordo com Oliveira Filho (2009) e D’Ambrósio (1987), o Movimento Matemática Moderna no Brasil foi diretamente influenciado pelas ideias propostas pelo SMSG. Os mesmos autores afirmam, também, que a coleção de livros didáticos deste Grupo, destinada para o colégio, teve sucesso e reconhecimento no país. Não encontramos, entretanto, pesquisas que se dedicassem a estudar as obras produzidas pelo SMSG para o ginásio. Então, devido à falta de estudos sobre essa coleção, da dificuldade para encontrar os livros que a compõem, e do sucesso de coleções para as mesmas séries escolares, acreditamos que as obras produzidas para o curso ginasial não tiveram acolhimento e aceitação significativos no Brasil. Os volumes que encontramos para apoiar esta nossa investigação são, todos, a primeira edição, e sua diagramação é ainda bastante tosca. Disso inferimos - mesmo sem ter em mãos os dados oficiais sobre tiragem e reimpressões - que a coleção para o Ginásio foi editada uma única vez. Seu tímido acolhimento pelo mercado, consequentemente, parece ter inviabilizado reedições e aprimoramentos de diagramação e, talvez, o quarto volume nem tenha sido produzido e/ou circulado mais amplamente. Como parte de sua estratégia de alteração curricular efetiva, o SMSG criava materiais didáticos em caráter experimental, de modo que pudessem ser acolhidas, em edições posteriores, as sugestões dos mais distintos agentes envolvidos com o sistema educacional. Ainda que seja uma experimentação de natureza distinta, também a produção da versão brasileira da coleção para o Ginásio foi experimental, mais voltada talvez à prospecção de um público alvo, uma experimentação que visava a detectar as condições do mercado livreiro - voltada,

deformaram o ideário da Matemática Moderna - bastante comum na literatura sobre o tema - não é a que defendemos neste trabalho (talvez esse seja, inclusive, um ponto central de diferenciação a ser destacado): ao que, no sentido usual, tem sido chamado de "deformação", nós chamamos de "apropriação" ou "mobilização". Não se trata, portanto, de alterar algo posto, dado e conhecido, mas atribuir um significado que induz a práticas determinadas de acordo com o significado atribuído. Uma "deformação" do Movimento Matemática Moderna é, segundo nosso ponto de vista, uma "atribuição de significado" ao Movimento, uma apropriação (ainda que o termo "apropriar", no sentido de "tornar próprio, incorporar" esteja vinculado à existência de uma forma prévia, a um significado imanente, correto, anterior, que também gostaríamos de evitar). A atribuição de significado cria, por assim dizer, um objeto. No caso, cria um movimento - ou uma versão do movimento - Matemática Moderna. 
portanto, a consumidores -, enquanto a experimentação original, ditada pela proposta do SMSG, voltava-se à recepção do material por seu público alvo: professores e alunos. De qualquer modo, o lançamento de uma coleção nova - seja para avaliar o impacto do mercado ou o impacto da abordagem proposta pelo texto - acaba refletindo, de algum modo, no sistema escolar.

Nota-se, no corpo do livro, uma ênfase às referências históricas, aí incluída a História do Presente, um dos motes centrais do Movimento: fala-se da Era Espacial, dos satélites, das novas tecnologias e da importância da Matemática como aplicação para a criação de um presente que se prepara para um futuro que nos aguarda logo à porta. Os livros apostam na criação de um ambiente e de um hábito de estudos em que prepondera 0 desenvolvimento de algumas habilidades e competências julgadas necessárias para suprir a carência de profissionais do país. Em vários momentos solicita-se dos alunos que recorram a outras fontes para fazer exercícios e responder problemas, tomando-os como que pesquisadores, capazes de operacionalizar informações que não Ihes foram dadas anteriormente. Da mesma forma, nota-se um esforço em desenvolver o raciocínio dedutivo e lógico dos estudantes por meio dos diversos exercícios em que é necessário deduzir proposições, propriedades e fórmulas e mesmo dar sentido a afirmações usualmente tidas como "postas", aprioristicamente dadas sem discussão. Ainda que, segundo muitos professores e pesquisadores, a ênfase no conceito de conjunto e de estruturas algébricas caracterize, do ponto de vista dos conteúdos, a Matemática Moderna (o que chega a se tornar uma característica hegemônica do Movimento) ${ }^{23}$, não se nota, nos volumes da coleção do SMSG para o ginásio, essa marca de modo tão significativo. Embora existam, sim, referências aos conjuntos e embora o cuidado com a formalização esteja presente, deve-se pontuar que, nesta coleção, o tratamento dado a esses tópicos é bem menos "agressivo" do que aqueles que podemos detectar em outros livros da época ${ }^{24}$. No primeiro volume da coleção do SMSG para o ginásio, o conceito de conjuntos é introduzido formalmente ${ }^{25}$ somente no quinto tópico do terceiro capítulo. De forma geral, os estudos são apresentados por meio de uma linguagem simples, com a introdução de poucos símbolos matemáticos, sendo explicada detalhadamente o uso e a função de cada um deles. Em alguns casos é dedicado um tópico do capítulo apenas para esse estudo, como é o caso do tópico de número 4, do quarto capítulo, "Nomes e Símbolos", dedicado ao estudo de Geometria Não-Métrica.

A Matemática Moderna divulgada no Brasil, como sabemos, está fortemente ligada aos cursos e materiais produzidos pelo GEEM, grupo cujo coordenador foi o professor Osvaldo Sangiorgi, que representou o Brasil junto ao grupo de estudos de Illinois, no período em que esteve na Universidade dos Kansas. O professor Lafayette, em sua entrevista, fala sobre uma espécie de rivalidade entre o SMSG - com o qual, no mesmo período, o prof. Lafayette se envolveu - e o grupo de Illinois.

\footnotetext{
23 Embora haja, também, pesquisadores segundo os quais a ênfase na Teoria dos Conjuntos é, já, uma deformação do ideário inicialmente proposto.

24 Um cotejamento de livros didáticos do período foi, de modo geral, desenvolvido em paralelo a esta investigação. Mais particularmente, nos detivemos na análise do Matemática - Curso Ginasial (foco da investigação) e em manuais do prof. Sangiorgi.

${ }^{25}$ Antes desse momento, o termo conjunto é utilizado de forma intuitiva.
} 
[...] alguns países mandaram algumas pessoas para o EUA para ver o que estavam fazendo por lá. Eu fui para Nova Iorque para conhecer o trabalho do SMSG. Fiquei internado na Fordham University (o Sangiorgi foi para o Kansas, com bolsa da Pan American Union e da NSF, para o grupo de Illinois. Esses grupos eram praticamente rivais nos EUA. (Lafayette de Morais, depoimento oral).

Assim, percebemos que, apesar do reconhecimento internacional do SMSG, havia outro grupo de estudos que poderia não compartilhar dos seus ideais, promovendo uma outra abordagem (uma outra apropriação?) ao ensino de Matemática. Além disso, Búrigo (1988) afirma que o GEEM, como propulsor do movimento no Brasil, em especial no estado de São Paulo, buscou compatibilizar projetos de diferentes países, produzindo um modo de entender próprio, elaborando uma nova síntese do Movimento. Segundo a autora, "[...] a divulgação da matemática moderna não foi feita através da simples tradução de textos estrangeiros, nem foi planejada por assessores estrangeiros como um desdobramento de um projeto elaborado de outro país" (p. 10).

Ao analisarmos as obras do SMSG e do professor Sangiorgi, notamos algumas diferenças marcantes já nos paratextos iniciais. A capa, por exemplo, nos livros produzidos pelo SMSG, traz figuras geométricas discretamente traçadas, o título e poucas cores, enquanto o livro Matemática: Curso Moderno, de Sangiorgi, tem uma capa vibrantemente colorida, com informações cobrindo todo o espaço disponível. No título observa-se também - como em várias obras publicadas à época - o adjetivo "moderno" que não consta dos livros produzidos pelo SMSG ${ }^{26}$. Ainda que nos Estados Unidos a expressão usada para o movimento tenha sido "Nova Matemática" (New Math), notamos que nem mesmo o adjetivo "nova" consta das produções do SMSG. No Brasil, certamente o uso do adjetivo "moderno" tinha uma função mercadológica e a intenção de vincular uma proposta didática a uma política de governo, intensiva, de modernização dos sistemas de produção, dos transportes e da indústria. Lydia Lamparelli ressalta algo similar à diferença que estamos discutindo quando afirma que nos livros norte-americanos "[...] não tinha nada daquele marketing que se viu depois nos livros didáticos brasileiros que surgiram, autodenominados Matemática Moderna". (SOUZA, 2005, p. 143).

Com relação à abordagem dos conteúdos, notamos que na obra do professor Sangiorgi há uma ênfase, bastante explícita, na teoria dos conjuntos e em aspectos formais da matemática, como as demonstrações. No primeiro volume dessa coleção do autor brasileiro, composta por quatro tomos (um para cada ano do curso ginasial), já a primeira parte do primeiro capítulo é dedicada ao estudo dos conjuntos o que o tornava o primeiro conteúdo com o qual os estudantes se defrontavam no início dos seus estudos secundários.

\footnotetext{
${ }^{26}$ Nesse sentido é interessantíssima a afirmação de Scipione de Pierro Neto acerca do título de uma de suas coleções: "Havia tanta paixão, tanto interesse, interesse comercial, que o meu primeiro editor, em 1967, diz, - 'Seu livro vai chamar Matemática Moderna', e eu disse - 'Nunca, não tem que chamar Matemática Moderna', eu falava - 'Jamais'. Aí um dia eu telefonei para ele e falei 'Paulinho', ele chama-se Paulo, 'Paulinho, eu descobri um título para colocar no livro: Matemática para Escola Moderna'. Ele falou - 'Ótimo, Scipione, ótimo. A gente põe 'Matemática' com letra grande, 'para a escola' em letra pequenininha, e 'Moderna' em letra grande'. Por aí vocês vêem o interesse comercial como era. E eu não consegui demover o editor... o 'para a escola' ficou bem pequeno".
} 
No texto introdutório ao seu livro, Sangiorgi dirige-se aos estudantes, afirmando que eles já foram iniciados "no estudo da Matemática de um modo diferente daquele pelo qual seus irmãos e colegas mais velhos estudaram", principalmente porque a matemática deixa de ser um emaranhado de cálculos, de problemas difíceis e fora da realidade, sendo essas tarefas deixadas a cargo dos computadores, produzidos na Era Atômica. O ensino de matemática, passa, então, a focalizar "o verdadeiro significado e as belas estruturas da Matemática Moderna", sendo possivel perceber uma semelhança entre a Matemática e as outras matérias, como Português, História, Geografia etc. Os autores do SMSG também apostam e explicitam a importância do vínculo entre a matemática em outras disciplinas, buscando incentivar o seu estudo, devido a sua grande aplicabilidade, entretanto, o modo como se dirigem aos estudantes os tradutores da coleção do SMSG é menos agressiva, intensificando menos a comparação entre uma "nova" forma de ver e o modelo "antigo" de estudar matemática. Não há, nos textos introdutórios da edição brasileira do SMSG, essa exacerbação da dicotomia entre "novo" (avançado, progressista, bom) e "velho" (antiquado, ultrapassado).

Assim como houve uma resistência com relação aos livros produzidos pelo professor Sangiorgi para o Colégio, o mesmo ocorreu com o SMSG, no caso das obras destinadas ao Ginásio. Assim, cada autor dominou o mercado no nível de ensino em que investiram inicialmente: Sangiorgi - um autor que já tinha obras conhecidas e intensamente divulgadas e adotadas - no Ginásio; o SMSG no Colégio.

Durante a nossa análise, notamos ainda que a coleção analisada se aproxima, em muitos aspectos, aos livros didáticos de Matemática publicados, nos dias atuais, para 60,70, $8^{\circ}$ e $9^{\circ}$ anos do Ensino Fundamental (que equivalem ao antigo Ginásio). Além do programa adotado na obra, também a metodologia utilizada para trabalhar os conteúdos se assemelha muito à dos livros atuais, por exemplo, no que diz respeito tanto à articulação entre conceitos "antigos" (anteriormente apresentados no livro ou em outras séries) e novos, quanto às relações entre diferentes conceitos, algoritmos e procedimentos; e ao vínculo entre a matemática e outras ciências. Para introduzir conceitos e ideias matemáticas mobiliza-se a história da matemática, conforme observamos em diferentes capítulos, em especial nos capítulos 2 e 6 do primeiro volume, que abordam os conteúdos de Numeração e Sistema de Números Racionais, respectivamente. Os conteúdos também são introduzidos por meio de exemplos e questões que podem estimular, problematizando. A linguagem matemática é introduzida de forma delicada, de um modo que julgamos pertinente e apropriado. O estudo, ao longo dos volumes considerados, é desenvolvido valorizando os conhecimentos e experiências que os estudantes adquiriram fora da escola, além de trazer, para a sala de aula, problemas cotidianos, uma clara tentativa do que ainda atualmente se expressa como uma tentativa de "contextualizar" o ensino. Além disso, acreditamos que o modo como os textos são construídos possibilita o desenvolvimento de habilidades como as de observar, explorar, investigar, generalizar, tomar decisões e questionar.

Assim, por meio das observações e aspectos que levantamos, percebemos que a obra Matemática - curso Ginasial se distancia em vários pontos das obras que marcaram o ensino de Matemática Moderna no Brasil e, de certa forma, afasta-se delas em termos de como os conteúdos são abordados e de como os recursos gráficos são mobilizados, podendo até ser considerada uma obra atual, quase meio século após a sua publicação. 


\section{Referências}

ANDRADE, M. M. Ensaios sobre o Ensino em geral e o de Matemática em particular, de Lacroix: Análise de uma forma simbólica à luz do Referencial Metodológico da Hermenêutica de Profundidade. 2012. 281 f. Tese (Doutorado em Educação Matemática), Universidade Estadual Paulista, Rio Claro, 2012

BUFFA, E.; NOSELLA, P. A educação negada: introdução ao estudo da educação brasileira contemporânea. 2ª ed. São Paulo: Cortez, 1997.

BARALDI, I. M. Retraços da Educação Matemática na Região de Bauru (SP): Uma História em construção. 2003. 240 f. Tese (Doutorado em Educação Matemática) - UNESP, Rio Claro, 2003.

BARALDI, I. M.; GAERTNER, R. Contribuições da CADES para a Educação (Matemática) Secundária no Brasil: uma Descrição da Produção Bibliográfica (1953-1971). BOLEMA, Rio Claro, v. 23, n. 35, p.159183, abr. 2010.

BRASIL. Ministério da Educação e Cultura. Lei 4.024, de 20 de dezembro de 1961. Lei de Diretrizes e Bases da Educação Nacional, 1961.

BRASIL. Ministério da Educação e Cultura. Lei 5.692, de 11 de agosto de 1971. Lei de Diretrizes e Bases da Educação Nacional, 1971.

BÚRIGO, E. Z. Movimento da Matemática Moderna no Brasil: estudo da ação e do pensamento de educadores matemáticos nos anos 60. 1989. 229 f. Dissertação (Mestrado em Educação) Universidade Federal do Rio Grande do Sul, Porto Alegre.

CANCIAN, R. O foco da resistência ao regime militar no Brasil. Disponível em: <http://educacao.uol.com.br/historia-brasil/movimento-estudantil-o-foco-da-resistencia-ao-regimemilitar-no-brasil.jhtm>. Acesso em: 07 jun. 2012.

CARVALHO, J. B. P. de. Políticas Públicas e o Livro Didático de Matemática. BOLEMA, Rio Claro, Ano 21, n. 29, p.1-11, 2008.

CARDOSO, V. C. A cigarra e a formiga: uma reflexão sobre educação matemática brasileira na primeira década do século XXI. 2009. 212 f. Tese (Doutorado em Educação), Universidade de Campinas - UNICAMP, 2009

D'AMBROSIO, B. S. The dynamics and consequences of the modern Mathematics Reform Movement for Brazilian Mathematics Education. 1987. 257 p. Tese (Doutorado em Filosofia) - Indiana University, Bloomington, Indiana.

GARNICA, A. V. M. . Registrar Oralidades para a História da Matemática e da Educação Matemática brasileira: o Movimento da Matemática Moderna. Zetetiké: UNICAMP, v. 16, p. 173-225, 2008.

GENETTE, G. Paratextos Editoriais. São Paulo: Ateliê Editorial, 2009.

HOBSBAWM, E. Era dos Extremos: o Breve Século XX (1914-1991). São Paulo, Companhia das Letras, 2003, $598 \mathrm{p}$.

LAVORENTE, C. R. A Matemática Moderna nos livros de Osvaldo Sangiorgi. 2008. 253 f. Dissertação (Mestrado em Educação Matemática) - Pontifícia Universidade Católica, São Paulo, 2008.

MARTINS-SALANDIM, M. E. A Interiorização dos Cursos de Matemática no Estado de São Paulo: Um exame da década de 1960. 2012. 372 f. Tese (Doutorado em Educação Matemática) - UNESP, Rio Claro, 2012.

MIORIM, M. A. Livros didáticos de matemática do período de implantação do movimento da matemática moderna no Brasil. In: $\vee$ Congresso ibero-americano de educação matemática, 2005, Porto. V CIBEM - Congresso ibero-americano de educação matemática. Porto: Faculdade de Ciências da Universidade do Porto, 2005. v. 1. p. 1-20. 
OliVEIRA, F. D. Análise de textos didáticos: três estudos. Dissertação (Mestrado em Educação Matemática). Universidade Estadual Paulista - UNESP, Rio Claro, 2008.

OLIVEIRA FILHO, F. O School Mathematics Study Group e o Movimento da Matemática Moderna no Brasil. Dissertação (Mestrado em Educação Matemática) - Universidade Bandeirante de São Paulo UNIBAN, São Paulo, 2009.

OLIVEIRA, M. C.; SILVA, M. C. L.; VALENTE, W. R. O Movimento da Matemática Moderna: História de uma Revolução Curricular. Juiz de Fora: Editora UFJF, 2011.

PARDIM, C. S. Orientações pedagógicas nas escolas normais de Campo Grande: um olhar sobre o manual Metodologia do Ensino Primário. 2013. Dissertação (Mestrado) - Curso de Educação Matemática, Universidade Federal do Mato Grosso do Sul, Campo Grande, 2013.

PILAGAlLO, O. A história do Brasil no Século 20: (1960 - 1980). 2. ed. São Paulo: Publifolha, 2009.

RICOEUR, P. O Conflito das Interpretações. Porto: Rés Editora, 1969.

ROLKOUSKI. E. Vidas de professores de Matemática: (im)possibilidades de leitura. Tese. Doutorado em Educação Matemática. IGCE, UNESP, Rio Claro, 2006.

SANGIORGI, O. Matemática: curso moderno, para os ginásios. São Paulo: Companhia Editora Nacional, 1967.

SILVA, T. T. P. da. Os Movimentos Matemática Moderna: compreensões a partir da análise da obra Matemática-Curso Ginasial, do SMSG. 2013. 171 f. Dissertação (Mestrado em Educação Matemática) - IGCE - UNESP - Rio Claro, 2013.

SMSG. Matemática - Curso Ginasial, Volume I, II e III. Tradução de Lafayette de Moraes, Lydia Conde Lamparelli e Colaboradores. São Paulo: EDART, 1967.

SOARES, F. Movimento da Matemática Moderna no Brasil: Avanço ou Retrocesso? 2001. 192 f. Dissertação (Mestrado em Educação Matemática) - Pontifícia Universidade Católica, Rio de Janeiro, 2001.

SOUZA, G. L. D. de. Educação Matemática na CENP: um estudo histórico sobre condições institucionais de produção cultural por parte de uma comunidade de prática. 2005. 432 f. Tese (Doutorado em Educação) - Faculdade de Educação - UNICAMP, Campinas, 2005.

SOUZA, L. A. de; GARNICA, A. V. M. As Matemáticas Modernas: Um Ensaio sobre os modos de Produção de Significado ao (s) Movimentos (s) no Ensino Primário Brasileiro. Revista Latinoamericana de Investigación En Matemática Educativa, México (no prelo).

SOUZA, L. A. de. Trilhas na Construção de Versões Históricas sobre um Grupo Escolar. 2011. 421 f. Tese (Doutorado em Educação Matemática) - UNESP, Rio Claro, 2011.

VALENTE, W. R. (Org.). Osvaldo Sangiorgi: Um Professor Moderno. São Paulo: Annablume, 2008b

THOMPSON, J. B. Ideologia e Cultura Moderna: Teoria social crítica na era dos meios de comunicação de massa. (Tradução do Grupo de Estudos sobre Ideologia, Comunicação e Representaç̃̃es Sociais). Petrópolis: Vozes, 1995.

WIELEWSKI, G. D. Políticas Educacionais e a Oficialização da Matemática Moderna no Brasil. In: Búrigo, E. Z.; Fischer, M. C. B.; Santos, M. B. A Matemática Moderna nas escolas do Brasil e de Portugal: Novos Estudos - Redes Editora, 2008. (p.22-34). 